\title{
TAKARAN PUPUK KALIUM TERHADAP HASIL BERBAGAI VARIETAS KEDELAI (Glycine max (L.) Merrill)
}

\author{
Dosage Potassium Fertilizer on the Yield of Soybean Varieties
}

(Glycine $\max (\mathrm{L}$.$) Merrill)$

\author{
Yudi Yusdian \\ Fakultas Pertanian Universitas Bale Bandung \\ yyudiyusdian.yahoo.com
}

\begin{abstract}
The objective of this research was to study the interaction effect between the dosage Potassium fertilizer and soybean varieties on the yield and also to get the optimum dosage Potassium fertilizer that give maximum yield of each soybean variety.The experiment was conducted at Tanjungwangi village, Pacet subdistrict, Bandung regency, West Java province. The altitude is about 745 mabove sea level. The average of rainfall was 1963,51 mm/year and the type of rainfall is C according to Schmidt and Fergusson (1951). The soil type is Inceptisol with $\mathrm{pH} 7,2$. The experiment was conducted from Oktober 2011 until January 2012. The experiment was arranged in experimental methode to split plot design with three replications. The main plot factor is a soybean varieties $(V)$ consisted of three varieties: $v_{1}=K a b a, v_{2}=$ Anjasmoro and $v_{3}=$ Willis, while the sub plot factor is a fertilizer dosage of $K_{2} O(K)$ consisting of three standards : $k_{1}=30 \mathrm{~kg} \mathrm{ha}^{-1}$, $k_{2}=60 \mathrm{~kg} \mathrm{ha}^{-1}$ and $k_{3}=90 \mathrm{~kg} \mathrm{ha}^{-1}$. The result showed that there was interaction effect between the dosage potassium fertilizer and soybean varieties on the number of filled pod, number of seed and seed weight per plant. The optimum dosage potassium fertilizer that could give maximum yield for each varieties: Kaba $61,80 \mathrm{~kg} \mathrm{ha}^{-1} \mathrm{~K}_{2} \mathrm{O}$, Anjasmoro 66,60 $\mathrm{kg} \mathrm{ha}^{-1} \mathrm{~K}_{2} \mathrm{O}$ and Wilis 72,60 $\mathrm{kg} \mathrm{ha}^{-1} \mathrm{~K}_{2} \mathrm{O}$.
\end{abstract}

Key word : potassium fertilizer, soybean varieties, growth and yield.

\section{PENDAHULUAN}

Kedelai (Glycine $\max (\mathrm{L}$.$) Merrill)$ merupakan salah satu jenis tanaman pangan yang memiliki prospek yang cukup cerah karena kedelai merupakan salah satu tanaman multiguna karena bisa digunakan sebagai pangan, pakan maupun bahan baku berbagai industri manufaktur dan olahan.

Peningkatan produksi kedelai dapat dilakukan melalui pengelolaan tanaman yang sesuai dan manipulasi tanah yang tepat. Penggunaan varietas unggul merupakan inovasi teknologi yang mudah diadopsi petani dan memberikan kontribusi yang signifikan dalam meningkatkan produksi (Marwoto dan Hilman, 2005). Varietas unggul memiliki sifat seperti hasil tinggi, umur genjah, dan tahan/toleran terhadap cekaman biotik (hama dan penyakit) dan abiotik (lingkungan fisik). Penggunaan varietas unggul yang digunakan perlu ditunjang dengan pemeliharaan salah satunya adalah pemupukan. 
Pupuk dapat berupa organik maupun anorganik yang diberikan ke dalam tanah dan atau melalui daun dengan maksud menambah unsur hara yang diperlukan tanaman, sehingga tanaman dapat tumbuh dan berproduksi dengan maksimal. Berdasarkan unsur hara yang diperlukan tanaman, maka harus disesuaikan dengan fungsinya terutama unsur hara makro dan mikro harus selalu tersedia, karena kekurangan salah satu unsur hara makro dan mikro akan menimbulkan gejala defisiensi pada tanaman.

Berdasarkan hasil analisis tanah sebelum percobaan diketahui bahwa tanah yang dipakai selama percobaan adalah ordo Inceptisol dengan $\mathrm{pH} \mathrm{7,2}$ (netral). Tekstur liat berdebu dengan kandungan $\mathrm{K}_{2} \mathrm{O}$ potensial yaitu 10,75 (rendah) dan $\mathrm{K}$ tersedia $0,19 \mathrm{cmol} \mathrm{kg}^{-1}$ (rendah). Berdasarkan data tersebut menunjukkan kandungan hara $\mathrm{K}$ yang rendah, dimana unsur $\mathrm{K}$ ini berperan penting sebagai aktivator dari berbagai enzim yang esensial dalam reaksi-reaksi fotosintesis dan respirasi, serta untuk enzim yang terlibat dalam sintesis protein dan pati (Benyamin Lakitan, 2001). Selain itu pemupukan Kalium memegang peranan yang sangat penting dalam meningkatkan produksi kedelai karena pupuk Kalium (K) merupakan salah satu unsur dari tiga unsur utama yaitu N, P dan K (Dedi Nursyamsi, 2006).

Tanaman kedelai memerlukan unsur $\mathrm{K}$ dalam jumlah yang relatif besar yaitu untuk menghasilkan 3 ton kedelai diperlukan K sebesar $52 \mathrm{~kg}$. Selama pertumbuhan vegetatif unsur $\mathrm{K}$ diserap dalam jumlah yang relatif besar, kemudian agak menurun setelah biji mulai terbentuk dan akhirnya penyerapan hampir tidak terjadi kirakira 2 - 3 minggu sebelum biji masak penuh. Namun dengan demikian biji kedelai mengandung $\mathrm{K}$ yang besar berkisar $60 \%$ dari jumlah $\mathrm{K}$ yang terdapat dalam tanaman (Suprapto, 2003).

Menurut Saifudin Sarief (1989) Kalium juga penting dalam proses fotosintesis, sebab apabila terjadi kekurangan kalium dalam daun, maka kecepatan asimilasi karbon dioksida $\left(\mathrm{CO}_{2}\right)$ akan menurun. Selain itu kalium berperan juga dalam membantu pembentukan protein dan karbohidrat. Penggunaan pupuk K pada setiap varietas kedelai (kaba, anjasmoro dan wilis) memerlukan $\mathrm{K}$ yang berbeda, hal itu sangatlah dipengaruhi oleh karakteristik penyerapan ion, seperti adanya sifat tanaman dalam menyerap ion sangat selektif, bersifat akumulatif dan dipengaruhi pula oleh faktor genetik. Sifat-sifat lain yang penting dalam karakteristik penyerapan ion oleh akar tanaman, adalah bergantung pula pada diameter ion yang akan diserap dan valensi ion yang akan diserap.

Bedasarkan rekomendasi pemupukan pada lahan kering atau tegalan dari Tim Balai Penelitian Tanah (2007), pupuk K diberikan dalam bentuk pupuk tunggal $\mathrm{KCl}$ dengan dosis $50 \mathrm{~kg} \mathrm{ha}{ }^{-1}$ pada tegalan berpotensi tinggi, sedangkan tegalan berpotensi sedang diperlukan $100 \mathrm{~kg} \mathrm{ha}^{-1}$, dan tegalan berpotensi rendah diperlukan $150 \mathrm{~kg} \mathrm{KCl} \mathrm{ha}^{-1}$. Dedi Nursyamsi (2006) menyatakan kebutuhan pupuk Kalium pada tanah Ultisol untuk tanaman kedelai untuk mencapai hasil maksimum adalah 210 $\mathrm{kg} \mathrm{ha}^{-1} \mathrm{KCl}, 190 \mathrm{~kg} \mathrm{ha}^{-1} \mathrm{KCl}$ dan $150 \mathrm{~kg}$ ha $^{-1} \mathrm{KCl}$, sedangkan untuk mencapai hasil optimum hanya $85,2 \mathrm{~kg} \mathrm{ha}^{-1} \mathrm{KCl}$. 
Berdasarkan hal tersebut penggunaan varietas menunjukkan interaksi nyata dengan kesuburan tanah. Dimana varietas yang terpilih untuk tanah-tanah miskin berbeda dengan yang disarankan untuk tanah-tanah yang lebih subur. Berdasarkan hasil penelitian pada berbagai varietas kedelai menunjukkan bahwa pada kondisi kesuburan tanah rendah, varietas-varietas baru berdaya hasil tinggi tidak dapat dikembangkan potensi sepenuhnya. Pada tanah subur, varietas tersebut akan menguras kesuburan tanah lebih cepat dan akhirnya hasil akan menurun apabila tidak tersedia unsur hara pengganti (Aisyah Suyono dkk, 2006)

\section{METODE PENELITIAN}

Penelitian ini bersifat verifikatif dengan melaksanakan eksperimen di lapangan. Adapun kegiatan percobaan dilaksanakan di desa Tanjungwangi, kecamatan Pacet, kabupaten Bandung, provinsi Jawa Barat, dengan ketinggian tempat 745 meter di atas permukaan laut.

Rancangan lingkungan yang digunakan dalam percobaan ini adalah Rancangan Petak Terbagi (Split Plot
Design). Petak utama (main plotfaktor) adalah varietas kedelai $(\mathrm{V})$ yang terdiri dari tiga taraf : $\mathrm{v}_{1}=$ Kaba , $\mathrm{v}_{2}=$ Anjasmoro, $\mathrm{v}_{3}=$ Wilis; Anak petak (sub plot faktor) adalah takaran pupuk $\mathrm{K}_{2} \mathrm{O}$ (K) yang terdiri dari tiga taraf: $\mathrm{k}_{1}=30$ $\mathrm{kg} \mathrm{ha}^{-1}, \mathrm{k}_{2}=60 \mathrm{~kg} \mathrm{ha}^{-1}, \mathrm{k}_{3}=90 \mathrm{~kg} \mathrm{ha}^{-1}$

Variabel perlakuan yang terdiri dari varietas kedelai sebagai petak utama (V) dan takaran pupuk $\mathrm{K}_{2} \mathrm{O}(\mathrm{K})$ sebagai anak petak, dan masing-masing diulang 3 kali, dengan demikian jumlah plot percobaan adalah $3 \times 3 \times 3=27$ plot percobaan. Setiap plot berukuran $2 \mathrm{mx}$ $1 \mathrm{~m}$.

\section{HASIL PENELITIAN}

Analisis data mengenai pengaruh Varietas dan takaran pupuk Kalium pada berbagai taraf dilakukan pada : Jumlah polong isi, Jumlah polong hampa, Jumlah biji, bobot 100 butir biji dan bobot biji tanaman ${ }^{-1}$.

\section{1) Jumlah Polong Isi}

Berdasarkan hasil analisis data menunjukkan bahwa terjadi interaksi antara Varietas dan Kalium terhadap jumlah polong isi per tanaman.

Tabel 1. Pengaruh Takaran Pupuk Kalium terhadap Jumlah Polong Isi Tanaman ${ }^{-1}$ Berbagai Varietas Kedelai

\begin{tabular}{|c|c|c|c|c|c|}
\hline \multirow{3}{*}{ Varietas Kedelai } & \multicolumn{5}{|c|}{ Takaran pupuk Kalium $\left(\mathrm{K}_{2} \mathrm{O}\right)$} \\
\hline & \multicolumn{2}{|l|}{$\mathrm{k}_{1}\left(30 \mathrm{~kg} \mathrm{ha}^{-1}\right)$} & \multicolumn{2}{|c|}{$\mathrm{k}_{2}\left(60 \mathrm{~kg} \mathrm{ha}^{-1}\right)$} & $\mathrm{k}_{3}\left(90 \mathrm{~kg} \mathrm{ha}^{-1}\right)$ \\
\hline & - ------- & ---- & ---- buah ---. & --- & ------------ \\
\hline $\mathrm{v}_{1}(\mathrm{Kaba})$ & $\begin{array}{r}125,33 \\
\mathrm{~B}\end{array}$ & $\mathrm{~b}$ & $\begin{array}{r}173,50 \\
\mathrm{C}\end{array}$ & $\mathrm{b}$ & $\begin{array}{r}98,17 \\
\mathrm{~A}\end{array}$ \\
\hline $\mathrm{v}_{2}$ (Anjasmoro) & $\begin{array}{r}98,00 \\
\mathrm{~A}\end{array}$ & $\mathrm{a}$ & $\begin{array}{r}100,50 \\
\mathrm{~A}\end{array}$ & $\mathrm{a}$ & $\begin{array}{r}95,67 \\
\mathrm{~A}\end{array}$ \\
\hline $\mathrm{v}_{3}$ (Wilis) & $\begin{array}{r}140,33 \\
\text { A }\end{array}$ & $\mathrm{b}$ & $\begin{array}{r}159,00 \\
\mathrm{~A}\end{array}$ & $\mathrm{~b}$ & $\begin{array}{r}153,00 \\
\mathrm{~A}\end{array}$ \\
\hline
\end{tabular}


Pada Tabel 1 menunjukkan penggunaan varietas Kaba dan Wilis dengan takaran pupuk Kalium $\mathrm{k}_{1}(30 \mathrm{~kg}$ $\left.\mathrm{ha}^{-1} \mathrm{~K}_{2} \mathrm{O}\right)$ dan $\mathrm{k}_{2}\left(60 \mathrm{~kg} \mathrm{ha}^{-1} \mathrm{~K}_{2} \mathrm{O}\right)$ menunjukkan jumlah polong isi yang paling banyak dan berbeda nyata dibandingkan dengan varietas Anjasmoro, sedangkan penggunaan varietas Wilis dengan takaran pupuk Kalium $\quad \mathrm{k}_{3} \quad\left(\begin{array}{llll}\mathrm{kg} & \mathrm{ha}^{-1} & \mathrm{~K}_{2} \mathrm{O}\end{array}\right)$ menunjukkan jumlah polong isi yang paling banyak dan berbeda nyata dibandingkan dengan varietas Kaba dan Anjasmoro.

Pemupukan $\mathrm{K}$ yang diimbangi dengan $\mathrm{P}$ dapat meningkatkan kandungan total karbohidrat, lemak dan protein maksimum dalam biji (Shahidullah, Hossain, Rahman dan Quddus (1980). Sedangkan jika terjadi difisiensi $\mathrm{K}$ menyebabkan degradasi klorofil dengan menurunnya kandungan klorofil, meningkatnya resistensi difusi stomata dan mesophyl terhadap $\mathrm{CO}_{2}$ bersih oleh daun dan biji yang mengakibatkan menurunnya laju fotosintesis,bahkan sampai di bawah taraf ambang karena kekurangan sintesis RuBPcase (Peoles dan David, 1980).

\section{2) Jumlah Polong Hampa}

Berdasarkan hasil analisis data menunjukkan bahwa tidak terjadi interaksi antara Varietas dan Kalium terhadap jumlah polong hampa tanaman ${ }^{1}$, tetapi pengaruh mandiri takaran pupuk Kalium berpengaruh terhadap jumlah polong hampa. Pada Tabel 2 menunjukkan penggunaan varietas Kaba, Anjasmoro dan Wilis memberikan pengaruh yang sama terhadap jumlah polong hampa kedelai. Sedangkan takaran pupuk Kalium $\mathrm{k}_{1}$ (30 $\left.\mathrm{kg} \quad \mathrm{ha}^{-1} \quad \mathrm{~K}_{2} \mathrm{O}\right)$ menunjukkan jumlah polong hampa yang paling banyak dan berbeda nyata dengan takaran pupuk Kalium lainnya $\mathrm{k}_{2}\left(60 \mathrm{~kg} \mathrm{ha}^{-1} \mathrm{~K}_{2} \mathrm{O}\right)$ dan $\mathrm{k}_{3}\left(90 \mathrm{~kg} \mathrm{ha}^{-1} \mathrm{~K}_{2} \mathrm{O}\right)$.

Tabel 2. Pengaruh Takaran Pupuk Kalium terhadap Jumlah Polong Hampa Tanaman ${ }^{-1}$ Berbagai Varietas Kedelai

\begin{tabular}{|c|c|c|}
\hline Perlakuan & Rata-rata Jumlah & Polong Hampa \\
\hline Varietas Kedelai (V) : & -------------------- buah & ----- \\
\hline $\mathrm{v}_{1}(\mathrm{Kaba})$ & 16,44 & $\mathrm{a}$ \\
\hline $\mathrm{v}_{2}$ (Anjasmoro) & 16,22 & $\mathrm{a}$ \\
\hline $\mathrm{v}_{3}$ (Wilis) & 16,61 & $\mathrm{a}$ \\
\hline \multicolumn{3}{|l|}{ Pupuk Kalium (K) : } \\
\hline $\mathrm{k}_{1}\left(30 \mathrm{~kg} \mathrm{ha}^{-1} \mathrm{~K}_{2} \mathrm{O}\right)$ & 20,61 & $\mathrm{~b}$ \\
\hline $\mathrm{K}_{2}\left(60 \mathrm{~kg} \mathrm{ha}^{-1} \mathrm{~K}_{2} \mathrm{O}\right)$ & 13,83 & $\mathrm{a}$ \\
\hline $\mathrm{k}_{3}\left(90 \mathrm{~kg} \mathrm{ha}^{-1} \mathrm{~K}_{2} \mathrm{O}\right)$ & 14,83 & $\mathrm{a}$ \\
\hline
\end{tabular}




\section{3) Jumlah Biji}

Berdasarkan hasil analisis data menunjukkan bahwa terjadi interaksi antara Varietas dan Kalium terhadap jumlah biji tanaman ${ }^{-1}$.

Pada Tabel 3 menunjukkan penggunaan varietas Kaba dan Wilis dengan takaran pupuk Kalium $\mathrm{k}_{1}(30 \mathrm{~kg}$ $\left.\mathrm{ha}^{-1} \mathrm{~K}_{2} \mathrm{O}\right)$ dan $\mathrm{k}_{2}\left(60 \mathrm{~kg} \mathrm{ha}^{-1} \mathrm{~K}_{2} \mathrm{O}\right)$ menunjukkan jumlah biji yang paling banyak dan berbeda nyata dibandingkan dengan varietas Anjasmoro, sedangkan penggunaan varietas Wilis dengan takaran pupuk Kalium $\mathrm{k}_{3}$ (90 $\mathrm{kg} \mathrm{ha}^{-1}$ $\mathrm{K}_{2} \mathrm{O}$ ) menunjukkan jumlah biji yang paling banyak dan berbeda nyata dibandingkan dengan varietas Kaba dan Anjasmoro.

Pengaruh suplai $\mathrm{K}$ terhadap legum (kedelai) dapat meningkatkan hasil biji dan meningkatkan kualitas biji (Bhangoo dan Acbritton, 1979). Pengaruh ini akan lebih menguntungkan lagi jika suplai $\mathrm{K}$ optimum dan imbangan yang sesuai dengan $\mathrm{N}$ dan $\mathrm{P}$ (Boswell dan Anderson, 1976).

\section{4) Bobot 100 B utir Biji}

Berdasarkan hasil analisis data menunjukkan bahwa tidak terjadi interaksi antara Varietas dan Kalium terhadap jumlah bobot 100 butir biji $\operatorname{tanaman}^{-1}$, tetapi pengaruh mandiri Varietas dan takaran pupuk Kalium berpengaruh terhadap bobot 100 butir biji.

Pada Tabel 4 varietas Anjasmoro menunjukkan jumlah bobot 100 butir biji yang paling berat dan berbeda nyata dibandingkan dengan varietas Kaba dan Wilis. Sedangkan takaran pupuk Kalium $\mathrm{k}_{2}\left(60 \mathrm{~kg} \mathrm{ha}^{-1} \mathrm{~K}_{2} \mathrm{O}\right)$ dan $\mathrm{k}_{3}\left(90 \mathrm{~kg} \mathrm{ha}^{-1}\right.$ $\mathrm{K}_{2} \mathrm{O}$ ) menunjukkan bobot 100 butir biji yang paling baik dan berbeda nyata dengan takaran pupuk Kalium k1 (30 kg $\mathrm{ha}^{-1} \mathrm{~K}_{2} \mathrm{O}$ ). Ukuran biji kedelai sangat dipengaruhi sifat genetik dan faktor lingkungan. Biji berperan sebagai limbung, sedangkan daun-daun yang telah membuka paling sedikit duapertiganya berfungsi sebagi sumber. Ukuran Limbung yang besar mendorong aktivitas enzim fotosintesis (RuDP Carboxylase) di dalam daun (Duarte dan Adam, 1972).

Tabel 3. Pengaruh Takaran Pupuk Kalium terhadap Jumlah Biji Tanaman ${ }^{-1}$ Bebagai Varietas Kedelai

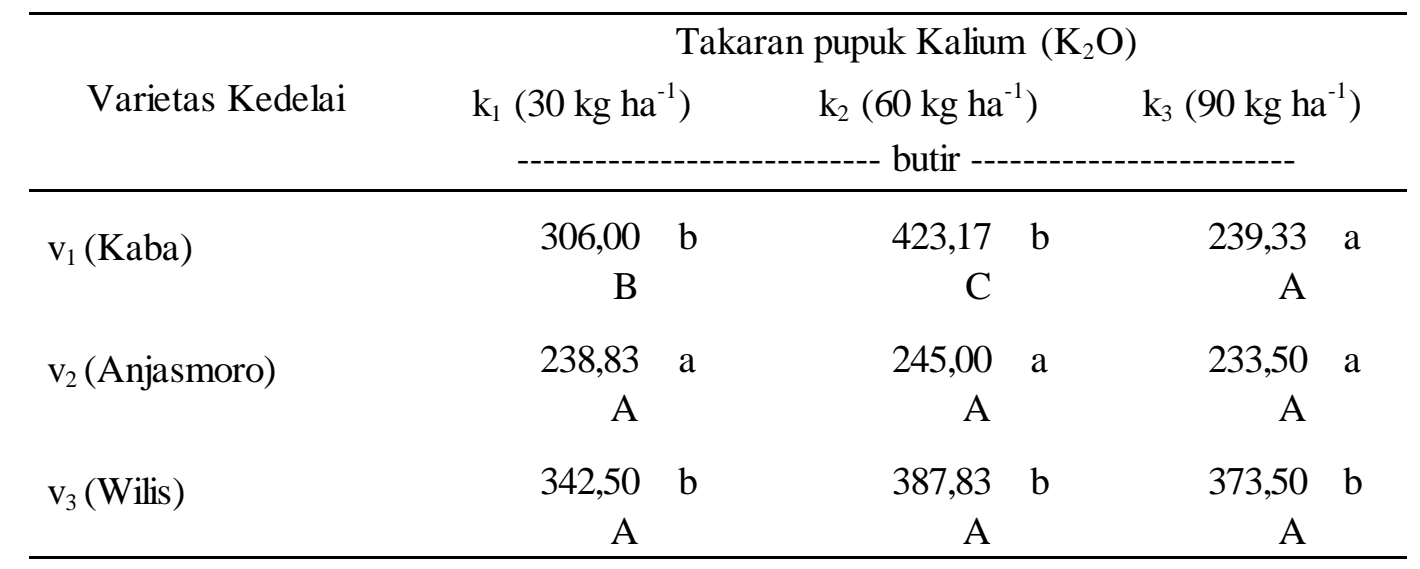


42 |PASPALUM VOL III No. 2 September 2015

Tabel 4. Pengaruh Takaran Pupuk Kalium terhadap Bobot 100 Butir Biji Berbagai Varietas Kedelai

Perlakuan Rata-rata Bobot 100 Butir Biji

Varietas Kedelai (V) :

g ---------------------

\begin{tabular}{lrl}
\hline $\mathrm{v}_{1}$ (Kaba) & 7,32 & $\mathrm{a}$ \\
$\mathrm{v}_{2}$ (Anjasmoro) & 11,24 & $\mathrm{~b}$ \\
$\mathrm{v}_{3}$ (Wilis) & 7,43 & $\mathrm{a}$
\end{tabular}

Pupuk Kalium (K) :

\begin{tabular}{lll}
$\mathrm{k}_{1}\left(30 \mathrm{~kg} \mathrm{ha}^{-1} \mathrm{~K}_{2} \mathrm{O}\right)$ & 6,78 & $\mathrm{a}$ \\
$\mathrm{K}_{2}\left(60 \mathrm{~kg} \mathrm{ha}^{-1} \mathrm{~K}_{2} \mathrm{O}\right)$ & 9,35 & $\mathrm{~b}$ \\
$\mathrm{k}_{3}\left(90 \mathrm{~kg} \mathrm{ha}^{-1} \mathrm{~K}_{2} \mathrm{O}\right)$ & 9,86 & $\mathrm{~b}$ \\
\hline
\end{tabular}

\section{5) Bobot Biji per Tanaman}

Berdasarkan hasil analisis data menunjukkan bahwa terjadi interaksi antara Varietas dan Kalium terhadap bobot biji tanaman ${ }^{-1}$. Pada Tabel 5 menunjukkan penggunaan varietas Anjasmoro dengan takaran pupuk Kalium $\mathrm{k}_{1}\left(30 \mathrm{~kg} \mathrm{ha}^{-1} \mathrm{~K}_{2} \mathrm{O}\right)$ menunjukkan bobot biji tanaman ${ }^{-1}$ yang paling berat dan berbeda nyata dibandingkan dengan varietas Kaba dan Wilis. Penggunaan varietas Wilis dengan takaran pupuk Kalium $\mathrm{k}_{2}\left(60 \mathrm{~kg} \mathrm{ha}^{-1}\right.$ $\mathrm{K}_{2} \mathrm{O}$ ) menunjukkan bobot biji $\operatorname{tanaman}^{-1}$ yang paling berat dan berbeda nyata dibandingkan dengan varietas Anjasmoro tetapi tidak berbeda nyata dengan varietas Kaba, sedangkan penggunaan varietas Wilis dengan takaran pupuk Kalium $\mathrm{k}_{3}\left(90 \mathrm{~kg} \mathrm{ha}^{-1}\right.$ $\mathrm{K}_{2} \mathrm{O}$ ) menunjukkan bobot biji $\operatorname{tanaman}^{-1}$ yang paling berat dan berbeda nyata dibandingkan dengan varietas Kaba dan Anjasmoro.

Berdasarkan hasil analisis regresi kuadratik terhadap bobot biji kering $\operatorname{tanaman}^{-1}$ dari beberapa varietas kedelai akibat pemberian takaran pupuk Kalium, dengan kurva respons hasil jumlah biji kering tanaman ${ }^{-1}$ terhadap berbagai varietas dan pemberian takaran pupuk Kalium disajikan pada Gambar 1.

Tabel 5. Pengaruh Takaran Pupuk Kalium terhadap Bobot Biji Tanaman ${ }^{-1}$ Bebagai Varietas Kedelai

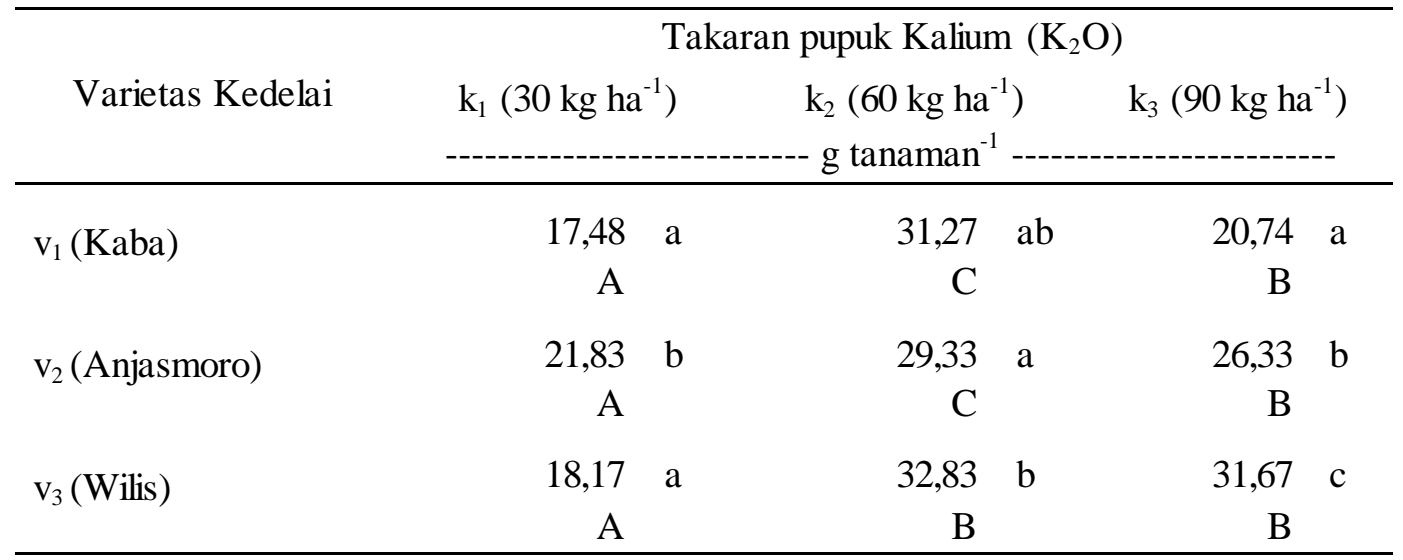


Berdasarkan hasil analisis regresi takaran pupuk $\mathrm{K}$ optimum untuk varietas Kaba yaitu sebesar $61,80 \mathrm{~kg} \mathrm{ha}^{-1}$ $\mathrm{K}_{2} \mathrm{O}$ mampu meningkatkan hasil maksimum bobot biji kering sebanyak $31.32 \mathrm{~g}$ tanaman $^{-1}$ yang ditunjukkan oleh persamaan regresi $\hat{\mathrm{Y}}_{-\mathrm{v}_{1 \mathrm{~K}}}=31,2667+$ $1,6333 X-12,1567 X^{2}$ dan $r^{2}=0,9834$ yang artinya $98,34 \%$ pupuk $\mathrm{K}$ berpengaruh terhadap pembentukan bobot biji kering $\operatorname{tanaman}^{-1}$ kedelai varietas Kaba, sedangkan takaran pupuk $\mathrm{K}$ optimum untuk varietas Anjasmoro yaitu sebesar 66,60 $\mathrm{kg} \mathrm{ha}^{-1} \mathrm{~K}_{2} \mathrm{O}$ mampu meningkatkan hasil maksimum bobot biji kering sebanyak 29,57 $\mathrm{g}_{\text {tanaman }}{ }^{-1}$ yang ditunjukkan oleh persamaan regresi $\hat{\mathrm{Y}}_{-\mathrm{v} 2 \mathrm{~K}}=29,3333+2,2500 \mathrm{X}$ $5,2500 X^{2}$ dan $r^{2}=0,9500$ yang artinya $95 \%$ pupuk $\mathrm{K}$ berpengaruh terhadap pembentukan bobot biji kering per tanaman kedelai varietas Anjasmoro.

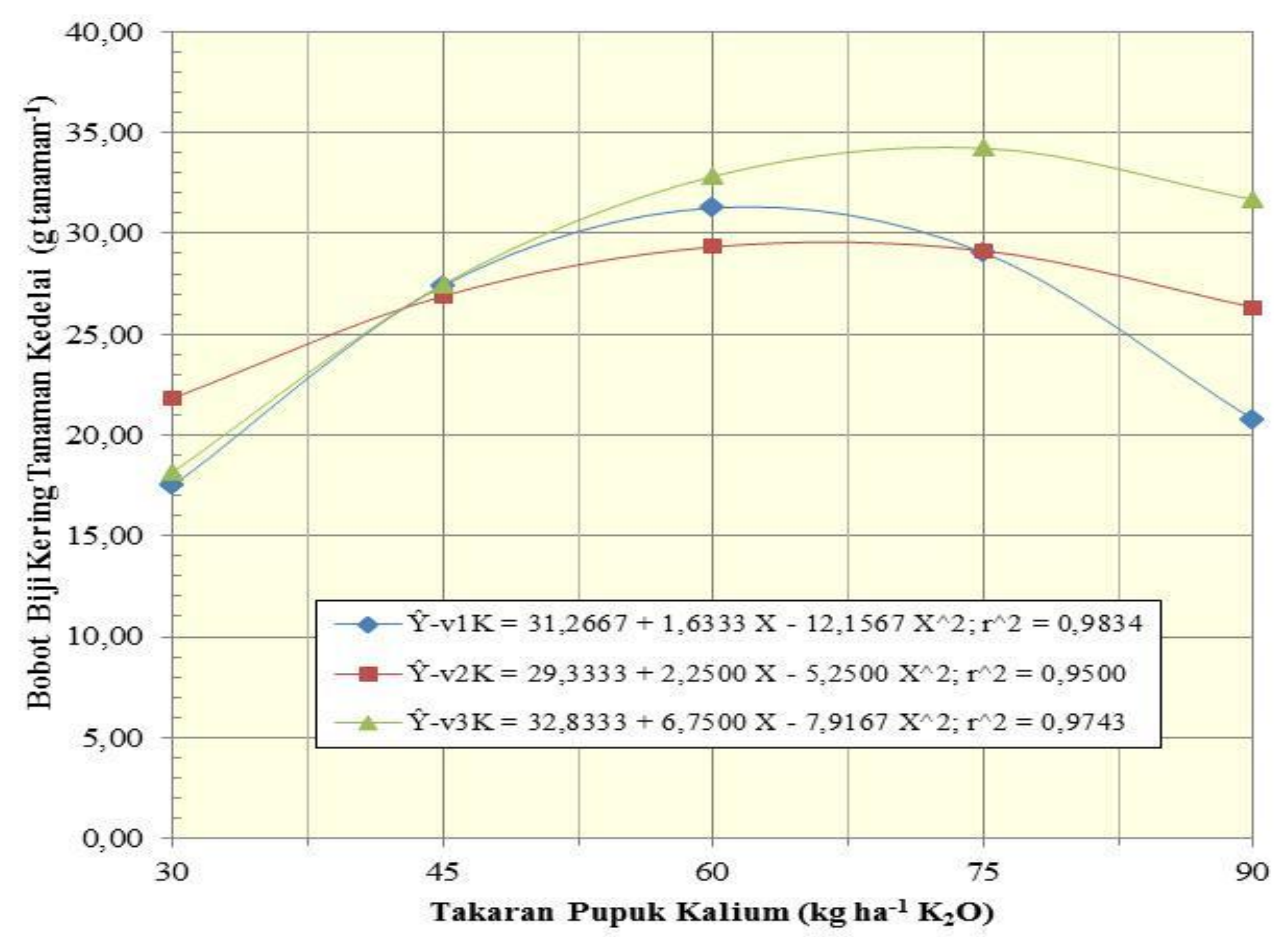

\begin{tabular}{lcc}
\hline Varietas Kedelai $(\mathrm{V})$ & $\begin{array}{c}\text { Takaran Pupuk Kalium } \\
\text { Optimum } \\
\left(\mathrm{kg} \mathrm{ha}^{-1} \mathrm{~K}_{2} \mathrm{O}\right)\end{array}$ & $\begin{array}{c}\text { Bobot Biji Kering } \\
\text { Maksimum } \\
\left(\mathrm{g} \mathrm{tanaman}^{-1}\right)\end{array}$ \\
\hline Kaba $\left(\mathrm{v}_{1}\right)$ & 61,80 & 31,32 \\
Anjasmoro $\left(\mathrm{v}_{2}\right)$ & 66,60 & 29,57 \\
Wilis $\left(\mathrm{v}_{3}\right)$ & 72,60 & 34,27 \\
\hline
\end{tabular}

Gambar 1. Kurva Respon Bobot Biji kering Tanaman ${ }^{-1}$ Berbagai Varietas Tanaman Kedelai Akibat Pemberian Takaran Pupuk Kalium 
Pada takaran pupuk $\mathrm{K}$ optimum untuk varietas Wilis yaitu sebesar 72.60 $\mathrm{kg} \mathrm{ha}^{-1} \mathrm{~K}_{2} \mathrm{O}$ mampu meningkatkan hasil maksimum bobot biji kering yang ditunjukkan oleh persamaan regresi $\hat{Y}$ $\mathrm{v}_{3 \mathrm{~K}}=32,8333+6,7500 \mathrm{X}-7,9167 \mathrm{X}^{2}$ dan $\quad r^{2}=0,9743$ yang artinya 97,43\% pupuk K berpengaruh terhadap pembentukan bobot biji kering tanaman ${ }^{1}$ kedelai varietas Wilis.

Pada kurva respons peningkatan pemupukan $\mathrm{K}$ sampai $90 \mathrm{~kg} \mathrm{ha}^{-1} \mathrm{~K}_{2} \mathrm{O}$ nampaknya terjadi penurunan kembali bobot biji kering $\operatorname{tanaman}^{-1}$, hal ini disebabkan pada semua varietas dengan takaran $\mathrm{K}$ yang berlebih menyebabkan terganggunya serapan hara lain. Perbedaan ini bervariasi, apalagi dibandingkan dengan karakteristik penyerapan ion seperti : (1) Selektivitas yaitu suatu unsur diserap secara istimewa lebih banyak, sedangkan unsur lain lebih sedikit malah ditolak, (2) Akumulasi yaitu konsentrasi ion dalam larutan sel lebih tinggi daripada di bagian luar sel dan (3) Genotip yaitu terdapat perbedaan yang nyata diantara spesies tanaman dalam menyerap ion.

Berdasarkan data tersebut menunjukkan bahwa setiap varietas kedelai (Kaba, Anjasmoro dan Wilis) membutuhkan takaran pupuk $\mathrm{K}$ yang berbeda untuk membentuk bobot biji kering tanaman kedelai. Dengan demikian respons tanaman terhadap $\mathrm{K}$ bertambah dengan bertambahnya laju penggunaan $\mathrm{N}$ dan $\mathrm{P}$, meningkatkan fiksasi $\mathrm{N}$ molecular, menambah kandungan protein mentah yang berbanding terbalik dengan kadar total minyak (Boswell dan Anderson, 1976).

Sedangkan tanpa penambahan K, kandungan $\mathrm{N}$ dan $\mathrm{P}$ dalam tanaman akan lebih rendah bahkan jika terjadi difisiensi $\mathrm{K}$ yang mengakibatkan menurunnya kandungan protein terutama pada bagian-bagian ujung, akar dan nodula. (Feigenbaum dan Mengel, 1980). Pengambilan K dilakukan dalam bentuk $\mathrm{K}^{+}$yang monovalen. $\mathrm{K}$ yang dapat dipertukaran dan yang ada dalam larutan tanah berada dalam keseimbangan, Pengambilan K terutama dilakukan dari larutan tanah (Mengel dan Kirkby, 1979), tetapi K sampai batas tertentu, dari bentuk-bentuk yang tidak dapat dipertukarkan. Walaupun $\mathrm{K}$ penting untuk tanaman, $\mathrm{K}$ bukanlah bagian penyusun tubuh tanaman. Unsur $\mathrm{K}$ disimpan dalam jumlah besar di dalam vakuola, $\mathrm{K}$ ini tidak membentuk ligand (molekul organik komplek), yang terutama berfungsi sebagai aktivator suatu enzim atau kofaktor dari sekitar 46 enzim. Kalium juga membantu memelihara potensial osmosis dan pengambilan air (Epstein, 1972).

Tanaman yang cukup $\mathrm{K}$ hanya kehilangan sedikit air karena $\mathrm{K}$ meningkatkan potensial osmotik dan mempunyai pengaruh positif juga terhadap penutupan stomata (Humble dan Hsiao, 1969). Kalium dapat juga berfungsi untuk menyeimbangkan muatan-muatan anion dan mempengaruhi pengambilan dan transport anion tersebut. Kalium berperan penting dalam fotosintesis karena secara langsung meningkatkan pertumbuhan dan indeks luas daun dan karenanya juga meningkatkan asimilasi $\mathrm{CO}_{2}$ serta meningkatkan translokasi hasil fotosintesis keluar daun. Translokasi meningkat karena pembentukan lebih banyak ATP yang penting untuk pemuatan hasil asimilasi ke dalam floem. 


\section{KESIMPULANDAN SARAN Kesimpulan}

Berdasarkan hasil analisis data pengamatan maka dapat ditarik kesimpulan sebagai berikut :

1. Terjadi interaksi antara takaran pupuk Kalium dan Varietas kedelai terhadap jumlah polong isi tanaman ${ }^{1}$, jumlah biji tanaman ${ }^{-1}$ dan bobot biji $\operatorname{tanaman}^{-1}$, sedangkan terhadap jumlah polong hampa tanaman ${ }^{-1}$ dan bobot 100 butir biji tanaman ${ }^{-1}$ tidak terjadi interaksi.

2. Takaran optimum pupuk Kalium yang dapat memberikan hasil bobot biji kering $\operatorname{tanaman}^{-1}$ maksimum untuk varietas Kaba adalah 61,80 kg ha $^{-1} \mathrm{~K}_{2} \mathrm{O}$, varietas Anjasmoro 66,60 $\mathrm{kg} \mathrm{ha}^{-1} \mathrm{~K}_{2} \mathrm{O}$ dan Varietas Wilis 72,60 $\mathrm{kg} \mathrm{ha}^{-1} \mathrm{~K}_{2} \mathrm{O}$.

\section{Saran}

Untuk memperoleh hasil penelitian yang lebih mantap dari pengaruh takaran kalium terhadap berbagai varietas kedelai, disarankan agar dilakukan percobaan yang sejenis dengan tempat dan waktu yang berbeda. Adapun takaran pupuk kalium yang dianjurkan untuk masing-masing varietas seperti Kaba adalah $61,80 \mathrm{~kg} \mathrm{ha}^{-1} \mathrm{~K}_{2} \mathrm{O}$, varietas Anjasmoro 66,60 kg ha ${ }^{-1} \mathrm{~K}_{2} \mathrm{O}$ dan Varietas Wilis 72,60 kg ha $\mathrm{K}_{2} \mathrm{O}$. Anjuran takaran pupuk Kalium ini diberikan bagi tanah yang berpotensi rendah.

\section{DAFTAR PUSTAKA}

Aisyah Suyono, Tien Kurniatin, Siti Mariam, Tanyid Syammusa, Maya Damanyani, Anni Yuniarti, Emma Trinurani Sofyan dan Yulianti Machfud. 2006. Kesuburan tanah dan Pemupukan. Jursan Ilmu Tanah Fakultas Pertanian Universitas Padjadjaran.

Benyamin Lakitan. 2001. Dasar-dasar Fisiologi Tumbuhan. PT. Raja Grafindo Persada Jakarta.

Bhangoo, M.S., dan D.Y. Acbritton. 1979. Effect of Fertilizer Nitrogen, Phosphorus and Potassium on Yield and Nutrient Content of Lee Soybean. Agron. J. 64:743-746.

Boswell, F.C., dan O.E. Anderson. 1976. Longterm Residual Fertility and Current N-P-K application Effect on Soybeans. Agro. J. 68.

Dedi Nursyamsi, 2006. Kebutuhan Hara Kalium Tanaman Kedelai di Tanah Ultisol. Jurnal Ilmu Tanah dan Lingkungan Vol. 6 (2) p.: 71-81. Bogor.

Duarte, R.A. and Adams. 1972. A Path Coeffisient Analysis of Some Yield Components Interrelation Field Bean. Crop Sci. 12 : 579582. 
Epstein, E. 1972. Minera; Nutrition of Plant. Principles and Perspectives. New York: Wiley.

Feigenbaum dan K. Mengel. 1980. The Effect of Reduced Linght Intensity and Sun Opti,al Potassium Supply on $\mathrm{N}_{2}$ Fixation and Turn Over in Rhizobium-Infected Lucerne. Soil and Fertilizer 43: Abstract; 585/p 69.

Humble, G.D. dan T.C. Hsiao. 1969. Plant Physiol. 46:483-87

Marwoto dan Y. Hilman. 2005. Teknologi Kacang-Kacangan Dan Umbi-Umbian Mendukung Ketahanan Pangan. Kinerja Balitkabi 2003-2004. Balitkabi. $20 \mathrm{hlm}$.

Mengel, K., and Kirkby 1980. Potassium in Crop Production. Adv. Agron. 33 : 59-110.
Peoles, T.R. dan David K. Koch. 1980. Role of Potassium in Carbondioxide Assimilation in Medicago sativa L. Potash Review. Subject 7.

Saifuddin Sarief. 1989. Kesuburan dan Pemupukan Tanah Pertanian. Pustaka Buana, Bandung.

Shahidullah, M., M.T. Hossain, M.A. Rahman dan Quddus M. 1980. Studies on Soybeans. 2. The Effect of Phosphorus and Potassium on the Growth, Yield Components, Yield and Nutrient Content of Soybean. Soil and Fertilizer 43. Abstract: 10549/p 1157

Suprapto, 2003. Bertanaman Kedelai. Penebar Swadaya. Anggota IKAPI. Jakarta.

Tim Balai Penelitian Tanah. 2008. Rekomendasi Pemupukan Tanaman Kedelai pada Berbagai Tipe Pnggunaan Lahan. Bogor. 